Article

\title{
Explaining Support for Sectarian Terrorism in Pakistan: Piety, Maslak and Sharia
}

\section{Christine Fair}

Edmund A. Walsh School of Foreign Service, Georgetown University, 3600 N. St., Washington, DC 2007, USA; E-Mail: ccf33@georgetown.edu; Tel.: +1-202-687-7898

Academic Editor: John L. Esposito

Received: 20 July 2015 / Accepted: 7 September 2015 / Published: 25 September 2015

\begin{abstract}
In the discourse around sectarian violence in Pakistan, two concerns are prominent. The first is the contention that piety, or the intensity of Muslim religious practice, predicts support for sectarian and other forms of Islamist violence. The second is the belief that personal preferences for some forms of sharia also explain such support. As I describe herein, scholars first articulated these concerns in the "clash of civilizations" thesis. Subsequent researchers developed them further in the scholarly and policy analytical literatures that explored these linkages through qualitative and quantitative methodologies. I revisit these claims in the particular context of sectarian violence in Pakistan. To do so, I use several questions included in a recent and large national survey of Pakistanis to create indices of both piety and support for three dimensions of sharia. I use these indices as explanatory variables, along with other explanatory and control variables, in a regression analysis of support for sectarian violence, the dependent variable. I find that the piety index and dimensions of sharia support are significant only when district fixed effects are excluded; however, personal characteristics (i.e., the particular school of Islam respondents espouse, ethnicity, several demographics) most consistently predict support for sectarian violence.
\end{abstract}

Keywords: sectarian violence; Pakistan; public support for terrorism

\section{Introduction}

Pakistan concentrates the attention of policy-makers and scholars for numerous reasons. With over 196 million Muslims, Pakistan's population is larger than the populations of Iran (80.8 million), Egypt (86.9 million) and Saudi Arabia (27.3 million) combined [1-4]. Its location has long been of strategic 
importance to the international community, as it sits astride the Middle East, Central Asia and South Asia. Most recently, Pakistan has been an important_albeit problematic_-US partner in the conduct of US and NATO-led military and stabilization operations in Afghanistan. Pakistan's madaaris (pl. of madrasah, religious schools) and institutions of higher Islamic studies attract scholars from the world over and thus Pakistan is an important leader in Islamic thought and scholarship across the Muslim world.

Pakistan is also a nuclear-armed state with the fastest growing arsenal in the world, inclusive of battlefield nuclear weapons [5,6]. As the revisionist state in the security competition with India, Pakistan has long sought to alter maps in Kashmir. To do so, Pakistan has started several wars with India in 1947-1948, 1965 and 1999 in effort to seize territory in that portion of Kashmir controlled by India. More worrisome, the Pakistani state has employed Islamist militants as tools to achieve the state's goals in India as well as Afghanistan since 1947, essentially when the state became independent from the erstwhile Raj [7-9]. With both India and Pakistan possessing nuclear weapons, analysts fear that such Pakistani provocations may incite the next war in South Asia with potential escalation to nuclear use.

While Pakistan sustains critical attention for all of these reasons, Pakistan is itself a site of Islamist militant activities. Pakistan's domestic Islamist terrorists have long targeted religious minorities, including Hindus and Christians, as well as others who consider themselves to be Muslims such as Shia, Barelvis and Ahmedis because these militant groups do not consider them to be Muslims. Disturbingly, it should be noted that many non-militants such as influential clerics, popular television talk show hosts and ordinary citizens in Pakistan share these views [10-13]. While Pakistanis are wont to blame the origins of these domestic militants upon the United States, India and even Israel; in fact, their origins are domestic. From late 2001 onward, many of Pakistan's one-time proxies began turning their guns against the state by taking on military, police and intelligence targets as well as civilian bureaucrats and political leaders [14].

As I detail herein, Pakistan's internal enemies have claimed more lives than all of Pakistan's wars combined, including the 1971 war in which Pakistan lost half of its territory and people. Given the lethal ferocity of Pakistan's internal enemies, in this paper I focus upon public support for groups who are the vanguard of such violence: sectarian militant groups. Sectarian militancy, defined as violence between different sects within Islam, began to emerge in 1979, as a result of domestic factors as well as regional and geopolitical developments. Since then, Pakistan has persistently experienced sectarian violence. While in the early 1980s sectarian groups included both Shia and Sunni militias, since the mid-1990s sectarian violence has almost exclusively been the purview of the anti-Shia organization, the Sipah-e-Sahaba and its related organization Lashkar-e-Jhangvi [15-18]. Both of these groups are now known as the Ahl-e-Sunnat wal Jamaat (ASWJ). While these groups are most known for their murdering of Shia, they also are the key perpetrators in the slayings of Ahmedis, Christians, Hindus, and Barelvis.

While Pakistan suffers a vast array of political violence with sanguinary consequences, in this paper I focus specifically upon Islamist militant violence generally and sectarian violence in particular within Pakistan itself [19]. The reasons for this particular focus are several. First, I hope to expand the debate about Pakistani Islamist violence. Contemporary discourse tends to frame Pakistan-based terrorist groups primarily in terms of the external threat they pose to Pakistan's neighbors and the international community, almost always at the behest of the Pakistani state. I want to remind analysts and scholars that many of the victims of Pakistan-based terrorist group are Pakistanis themselves, second only to the 
Afghans whose lives have been continuously imperiled by Pakistan's proxies since the early 1970s if not earlier [20].

Second, while Pakistan's sectarian killers continue to claim thousands of Pakistani lives, these sectarian groups, which are almost exclusively Deobandi, also share overlapping membership with other Deobandi militant groups including the Afghan Taliban, the Pakistani Taliban, and the so-called "Kashmiri tanzeems" that focus upon Kashmir and the rest of India, most notably the Jaish-e-Mohammad [16]. Pakistan's Deobandi sectarian terrorist groups have served as the principle sub-contractors for al-Qaeda in Pakistan as well [21]. These varied Deobandi militant groups also have important ties to the factions of the Deobandi Jamiat Ulema-e-Islami (JUI), which is a generally non-militant Islamist political party which regularly contests elections. This association with JUI leadership provides the militant groups with important political patrons and complicates government action against them.

Third, Pakistan's sectarian conflicts have long been inflected by extra-regional events such as the Iranian revolution, the Iran-Iraq war, and the anti-Soviet Jihad in Afghanistan and have had an adverse synergistic relationship with the Sunni Islamization of the state that began to unfold in the nation's earliest years [22]. This is currently the state of affairs with Saudi Arabia and Iran engaging in another bout of high-stakes sectarian brinkmanship in Iraq, Syria, Yemen and elsewhere. The consequences of these regional developments are significant because many of Pakistan's Deobandi sectarian militants have elected to join the Islamic State to kill Shia and Allawites in Iraq and Syria respectively [23-25].

In the discourse around sectarian violence in Pakistan and elsewhere, two prominent concerns come to the fore. The first is the notion that piety, or the intensity of Muslim religious practice, is a potential predictor for personal support for sectarian and other forms of Islamist violence. The second is the belief that individual conceptualizations of some forms of sharia also explain this support. As I describe herein, scholars first espoused these concepts in the "clash of civilizations" thesis [26,27]. Later writers advanced this discourse in scholarly and policy fora using qualitative and quantitative studies. In this paper, I use a new and large dataset collected by Fair et al. which is drawn from a recent and large national survey of Pakistanis [28]. The team's survey instrument collected several questions about different aspects of support for sharia as well as several dimensions of religious practice and piety. I use these various questions to create indices of both piety as well as support for three dimensions of sharia, described herein. I use these indices as explanatory variables, along with other explanatory and control variables such as sectarian background, in my regression analysis of support for sectarian violence, my dependent variable.

I find that the index of piety is a positive predictor of support for sectarian terrorism in Pakistan. In other words, persons who indicate greater piety are more likely to support sectarian violence than those with lower degrees of revealed piety. However, this significance disappears when I include district fixed effects in the model. (Including such fixed effects accounts for district-level characteristics for which I cannot explicitly control in my model). Those who espouse support for sharia in terms of good governance and restrictions upon women are less likely to support sectarian violence. Those who embrace the punitive dimensions of share are more likely to support this kind of violence. All three of these effects are not significant when district fixed effects are included in the model. In contrast, several other personal variables are more robust predictors than either piety or beliefs about sharia, including: the particular school of Islam (maslak) that respondents espouse, ethnicity and key demographics. 
The remainder of this paper is organized as follows. In the second section, I provide a brief background to the problem of sectarian militants in Pakistan and the vast array of violence they produce. Next, I detail the literatures in which I root these present queries and derive several hypotheses which I test subsequently. In the fourth section of this paper, I describe the dataset and analytical methods I employ. Fifth, I present the empirical findings. I conclude this essay with a brief discussion of the implications of this analysis.

\section{Sectarian and Other Violence in Pakistan: The Role of the Sipah-e-Sahaba-e-Pakistan}

While many Pakistani security managers decry the purported threat from India, in fact, the most vicious threat to the Pakistani state and citizens alike comes from Islamist militant organizations that engage in a wide array of terrorist attacks against ordinary civilians as well as assaults on non-combatants (e.g., political leadership). Many of these crimes are explicitly sectarian or communally motivated. Additionally, these militant groups have perpetrated guerilla campaigns against Pakistan's security forces and intelligence agencies as well. According to data collected by Bueno de Mesquita et al. [29], between 1988 and 2011, terrorist attacks have claimed the lives of 5783 Pakistanis $^{1}$ while another 35,839 Pakistanis were killed in other kinds of political violence, which include insurgent attacks upon state forces, communal violence, ethno-nationalist violence, etc. [29]. In contrast, Pakistani battlefield deaths over four wars (1947, 1965, 1971 and 1999) are fewer than 9000 - a full order of magnitude less than those killed in internal security events [30].

While most commentators on Pakistan's dire internal security situation tend to use the anodyne descriptors of "Islamist", "terrorist", or even "sectarian militants" to describe these groups, these expressions suffer from considerable under-specification. In fact, the groups that are primarily engaged in this kind of Islamist domestic violence against Pakistanis in and out of government are almost exclusively Deobandi, one of the five major interpretive traditions of Islam in Pakistan. Deobandis, like most Muslims in South Asia, follow the Hanafi School of fiqh, or jurisprudence ${ }^{2}$. This cluster of Deobandi militant organizations includes the sectarian (and communal) organization Ahl-e-Sunnat wal Jamaat (ASWJ), which is the name under which older Deobandi, sectarian groups such as Sipah-e-Sahaba-e-Pakistan (SSP) and Lashkar-e-Jhangvi (LeJ) now operate. These Deobandi groups have long-standing ties to the Afghan Taliban and consequently to al-Qaeda and to several Deobandi militant groups that the ISI groomed for operations in India (inter alia Jaish-e-Mohammad (JeM), Harkat-ul-Jihadi-e-Islami (HuJI), Harkat ul Mujahideen (HuA), Harkat ul Ansar (HuA)) [13,31,32]. These groups are often called "Kashmiri tanzeems" (Kashmiri organizations) even though few of their cadres are actually Kashmiri and they operate well beyond Kashmir.

1 Per the so-called BFRS [29] dataset "terrorist attacks" are defined by attacks on noncombatants conducted by violent groups in effort to advance a political goal. Sectarian attacks are a sub-set of these terrorist incidents in the BFRS dataset. Between 1988 and 2011, the BFRS dataset records 1724 deaths. This is most certainly an under-estimate because the BFRS coders could code an attack as "sectarian" only if the article described the attack in such terms.

2 In Pakistan, there are five main interpretative traditions of Islam (masalik, plural of maslak). In addition to the Shia maslak, which itself has multiple sects, there are four Sunni masalik: Barelvi, Deobandi, Ahl-e-Hadith, and Jamaat-e-Islami (which is also a political party that purports to be supra-sectarian). Each maslak has its own definition of sharia and looks to different sources of Islamic legitimacy. 
The so-called Tehreek-e-Taliban-e-Pakistan (TTP or Pakistani Taliban) also emerged from this morass of Deobandi militant groups, including the SSP [33]. While the TTP is often understood as a "Pashtun insurgency", in fact Punjab-based groups such as the Deobandi SSP/LeJ and JM are core components of the TTP and conduct attacks in its name [34]. The roots of the TTP stretch back to 2002, when Pakistan's Deobandi militant organizations began a serious reorganization. First, Jaish-e-Mohammad (JeM) fissured over General and President Pervez Musharraf's decision (whether voluntary or not) to facilitate US operations in Afghanistan to overthrow the Afghan Taliban. After all, the Taliban regime was, for most intents and purposes, the only extant Deobandi-inspired Islamist government. Masood Azhar, JeM's amir (leader) remained loyal to Pakistan while Jamaat-ul-Furqan, its breakaway rump, initiated suicide-operations against the state [14,35].

During the same period, important events began taking place in the Federally Administered Tribal Areas (FATA). After the US invasion of Afghanistan that began on 7 October 2001 many fighters associated with Al-Qaeda and the Taliban (inter alia Uzbeks, Uighers, Arabs, Afghans) sought sanctuary in the FATA and paid considerable amounts of money to locals who would support them and provide them with shelter and amenities. In 2002 when the Pakistan army began undertaking limited operations in FATA, specific tribal dimensions of the conflict began to manifest. At first, the Wazirs elected to fight the Pakistan army and later the Mehsuds — who had previously been loyal to the army — also enjoined the fight against the Pakistani army. By 2007, Mullah Nazir and Hafiz Gul Bahadur led a new formation called the "Muqami Tehreek-e-Taliban" (Local Taliban Movement). This group aimed to protect the interests of Wazirs in North and South Waziristan. Nazir and Bahadur formed this group "to balance the power and influence of Baitullah Mehsud and his allies, the Islamic Movement of Uzbekistan" ([14], p. 577). Notably both Nazir and Gul Bahadur forged a pact with the Pakistan army whereby they would desist from attacking the Pakistan army and focus all of their efforts upon ousting the US/NATO troops from Afghanistan and helping to restore the Afghan Taliban to power [36,37]. Other tribal lashkars (militias) also began forming to either challenge the Pakistan military or rivals. Some of the commanders began espousing the appellation of the "Pakistani Taliban".

These various Deobandi militias successfully forged a tentative archipelago of sharia (Islamic law) that arched across the Pashtun belt in the FATA and Khyber Pakhtunkhwa (KPK). Analysts generally cite 2007 as the year that the TTP formally coalesced. In November of that year, several Pakistani militant commanders, rallying under the leadership of Baitullah Mehsud, announced that they would henceforth operate under the banner of the Tehreek-e-Taliban-e-Pakistan (Pakistani Taliban Movement). Following Baitullah Mehsud's death in a 2008 drone strike, Hakimullah Mehsud took over the TTP. Under Hakimullah, the TTP became more coherent and intensified its campaign of suicide bombings of Pakistani security and intelligence agencies [38-40]. Under the leadership of Hakimullah, TTP campaigns against civilian targets also became more vicious, singling out Shia and Ahmedis (also spelled Ahmediyyas), who are considered munafiqin (Muslims who spread discord in the community) and murtad (liable to be killed), respectively [41].

The TTP has also attacked important Sufi shrines. While this is a new phenomenon that had no precedent in Pakistan, since 2005, militants have launched more than 70 suicide attacks on such sites, killing hundreds. These attacks against Sufis have intensified in recent years. For example, Lahore's prominent Datta Ganj Bakhsh — perhaps the most important Sufi shrine in the Punjab — was attacked in late June $2010[42,43]$. In October of that year, TTP attacked the shrine dedicated to a saint named 
Abdullah Shah Ghaz in Karachi [44]. In April 2011, suicide bombers assaulted a shrine dedicated to a Punjabi saint, Sakhi Sarvar, in Dera Ghazi Khan [45]. These and other Pakistani Taliban attacks have cumulatively served to deter Pakistanis from frequenting such shrines [46]. In May of 2015, gunmen from a sectarian group operating under the name of Jandullah boarded a bus of Ismailis (a Shia sect) and began gunning them down. Before the carnage was over, at least 43 were dead. Jundullah is a confederate of the Pakistani Taliban and Lashkar-e-Jhangvi and pledged allegiance to the Islamic state in November $2014[47,48]$.

The focus on sectarian violence against Shia, Barelvis, Ahmedis, and others no doubt reflected Hakimullah Mehsud's long-time association with the sectarian terrorist group SSP/LeJ [49]. In November 2013, a US drone strike killed Hakimullah [50]. Maulana Fazlullah became the amir of the TTP. Fazlullah had previously achieved notoriety with the moniker "Maulana Radio" and as head of the Tehreek-e-Nifaz Shariat-e-Muhammadi (TNSM), an Islamist militant group in Swat that first agitation for the imposition of sharia in Swat in the 1990s. After resuming these demands with a sustained campaign of terrorism that lasted several years, in 2009, the TNSM wrested an agreement (called Nizam-e-Adl, "System of Justice") from the Pakistani government for Swat and Malakand [51] However, when the TNSM broke the accord, the Pakistan army moved in quickly to crush the movement. Scholars believe that Fazlullah now resides in Kunar province in Afghanistan. He rarely issues statements [52]. The most sectarian commanders of the TTP, particularly those associated with the $\mathrm{SSP} / \mathrm{LeJ}$ are turning away from their traditional allegiance to the Afghan Taliban leader, previously Mullah Omar and now Mullah Mounsour, and are embracing the Islamic State [53].

The SSP (aka LeJ and ASWJ) and virtually all other Deobandi militant groups in Pakistan and Afghanistan are not only networked with each other, they are all tightly aligned with Islamist political organizations, most notably various factions the Deobandi ulema political party, the Jamiat Ulema-e-Islami (JUI)-Fazlur Rehman and JUI-Sami ul Haq. These Deobandi militant groups also enjoy funding by wealthy Arab individuals and organizations [16,54]. In addition, the SSP itself is a political party, which makes it difficult to completely disambiguate violent Islamist politics and non-violent Islamist politics. Given the role of coalitions in forming a government in Pakistan, numerous parties have partnered with SSP including President Musharraf's "King's Party" the Pakistan Muslim-Qaid, the Pakistan Peoples' Party (a left-of-center national political party with many Shia leaders) as well as the Pakistan Muslim League-Nawaz among others [17,33,55].

While Deobandi terrorists groups are mostly responsible for sectarian violence in Pakistan, Ahl-e-Hadith organizations have also targeted Barelvis and others as well, albeit with far less frequency. It is important to note that the Lashkar-e-Taiba, an Ahl-e-Hadith terrorist group, has never attacked targets in Pakistan [56]. Notable anti-Sunni, Shia groups exist (Sipah-e-Mohamad Pakistani (SMP) and Tehrik-e-Jafria-Pakistan (TJP)) and enjoyed support from Iran in the past. These groups are not nearly as active as their Deobandi counterparts today and mostly engage in tit-for-tat killings in response to Shia assassinations. In the growing sectarian violence, observers worry that Iran may once again enter this arena of sectarian proxies with verve. In recent years, especially in areas like the tribal agency of Kurram where Sunni militants have targeted Shia, Shia militias have formed in small numbers ([24], pp. 9-11). In recent years, Pakistan's Barelvis have begun attacking Deobandis in retaliation. Barelvis are also often involved in acts of political violence centered on blasphemy issues in Pakistan [57]. Barelvis have taken up violence against Deobandis in Pakistan as well [17,57,58]. 
Unfortunately, the activities of these sectarian militant groups are directly and indirectly sustained by Islamist and right-of-center political parties that are not overly militant. For example, Prime Minister Nawaz Sharif's Pakistan Muslim League (PML-N) has resisted cracking down on the sectarian groups for fear of alienating their sympathizers while Imran Khan's Pakistan Tehreek-e-Insaaf has advocated conciliatory policies towards the TTP $[59]^{3}$.

\section{Extent of the Problem?}

To provide an overview of the trends of domestic violence in Pakistan, I employ data on Pakistan's political violence, which were collected by Bueno de Mesquita and his colleagues using Pakistani press reports. Henceforth, I refer to this as the BFRS dataset [29]. Unlike most datasets on Pakistan, which focus only upon "terrorism", the BFRS dataset collects information about virtually every kind of political violence in Pakistan from the beginning of 1988 (when the anti-Soviet war was concluding) to the end of 2011. The BFRS dataset defines terrorism as political violence against non-combatants. An event is coded as "sectarian" if the news account explicitly characterizes the attack as sectarian, which we define as violence committed by one sect of Islam against another. This is distinct from communal violence which, in Pakistan, invariably involves Muslims attacking non-Muslims. In the BFRS dataset, an event is coded as communal or sectarian if there is information in the news account that identifies the attack in such terms. The BFRS data set also includes guerilla attacks, which are those conducted by militant groups against security forces. The BFRS dataset offers a further refinement: ethno-nationalist attack. These are most commonly involving Baloch or Sindhi separatists. Because these are not Islamist events and because sectarian groups do not engage in these attacks, I do not deal with ethno-nationalist violence here.

In Table 1, I divide the various incidents in this dataset into two periods: before and after 9/11. As the data in Table 1 show, even before the events of 9/11, Pakistan was a dangerous place for Pakistanis. In Figures 1-5, I geographically depict terrorist events by type and year aggregated at the district level for 1988, 2001, 2002, 2006 and 2011. These figures demonstrate a few important points. First, while much of Pakistan has experienced some form of domestic political violence, some districts remain free of violence most of the time. Second, sectarian, communal and guerilla violence seem to be confined to specific provinces and even districts. In other words, these forms of violence, despite the prevalence of reports in the news cycle, do not occur everywhere. Sectarian violence is most intensely concentrated in the Punjab in most years. In some years, it also has also occurred in parts of Sindh and the FATA. Communal violence is also mostly concentrated in the Punjab. Guerilla violence is generally concentrated in Balochistan (where the state has been at war with ethno-nationalist Baloch separatists) and in the FATA and parts of KPK where the state has been at war with the TTP and their confederates. What these maps also show is that the intensity of guerilla violence is a relatively recent phenomenon after 9/11. And as discussed above, much of this violence is due to the Pakistan Taliban and their sectarian and other allies. These charts alone attest to the importance of understanding Pakistan as a victim of political violence as well as an active exporter of the same.

3 Neither the PML-N nor the TTP are themselves directly purveyors of violence even if there are groups that may conduct political violence on their behalf on various occasions. It is common throughout South Asia for political parties to have armed militias and/or thuggish student wings [60]. 
Table 1. BFRS political violence.

\begin{tabular}{llll}
\hline Variable & $\mathbf{1 9 8 8 - 2 0 0 1}$ & $\mathbf{2 0 0 2 - 2 0 1 1}$ & Total: 1998-2011 \\
\hline Total Incidents, Terrorist Attacks & 2087 & 3721 & 5808 \\
Total Killed, Terrorist Attacks & 2086 & 3697 & 5783 \\
Total Wounded, Terrorist Attacks & 6754 & 9025 & 15,779 \\
Total Incidents, Sectarian Violence & 690 & 427 & 1117 \\
Total Killed, Sectarian Violence & 865 & 859 & 1724 \\
Total Wounded, Sectarian Violence & 1861 & 1414 & 3275 \\
Total Incidents, Other Political Violence & 11,340 & 12,820 & 24,160 \\
Total Killed, Other Political Violence & 10,873 & 24,966 & 35,839 \\
Total Wounded, Other Political Violence & 12,886 & 20,924 & 33,810 \\
\hline
\end{tabular}

Source: In-house tabulations of BFRS [29,61].

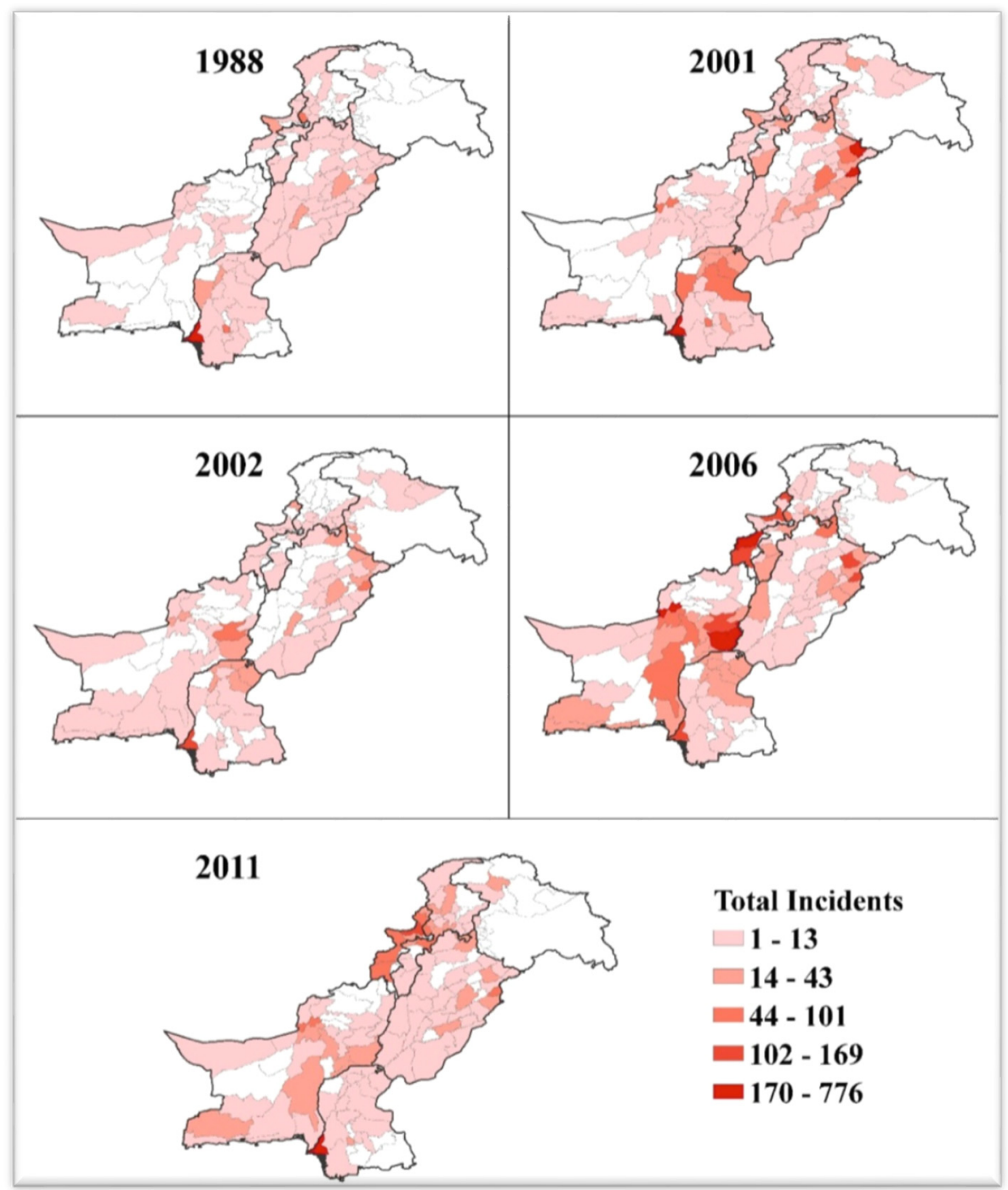

Figure 1. All Political Violence in Pakistan-Selected Years. Source: In-house manipulations of BFRS dataset $[29,61]$ by Jesse Turcotte. 


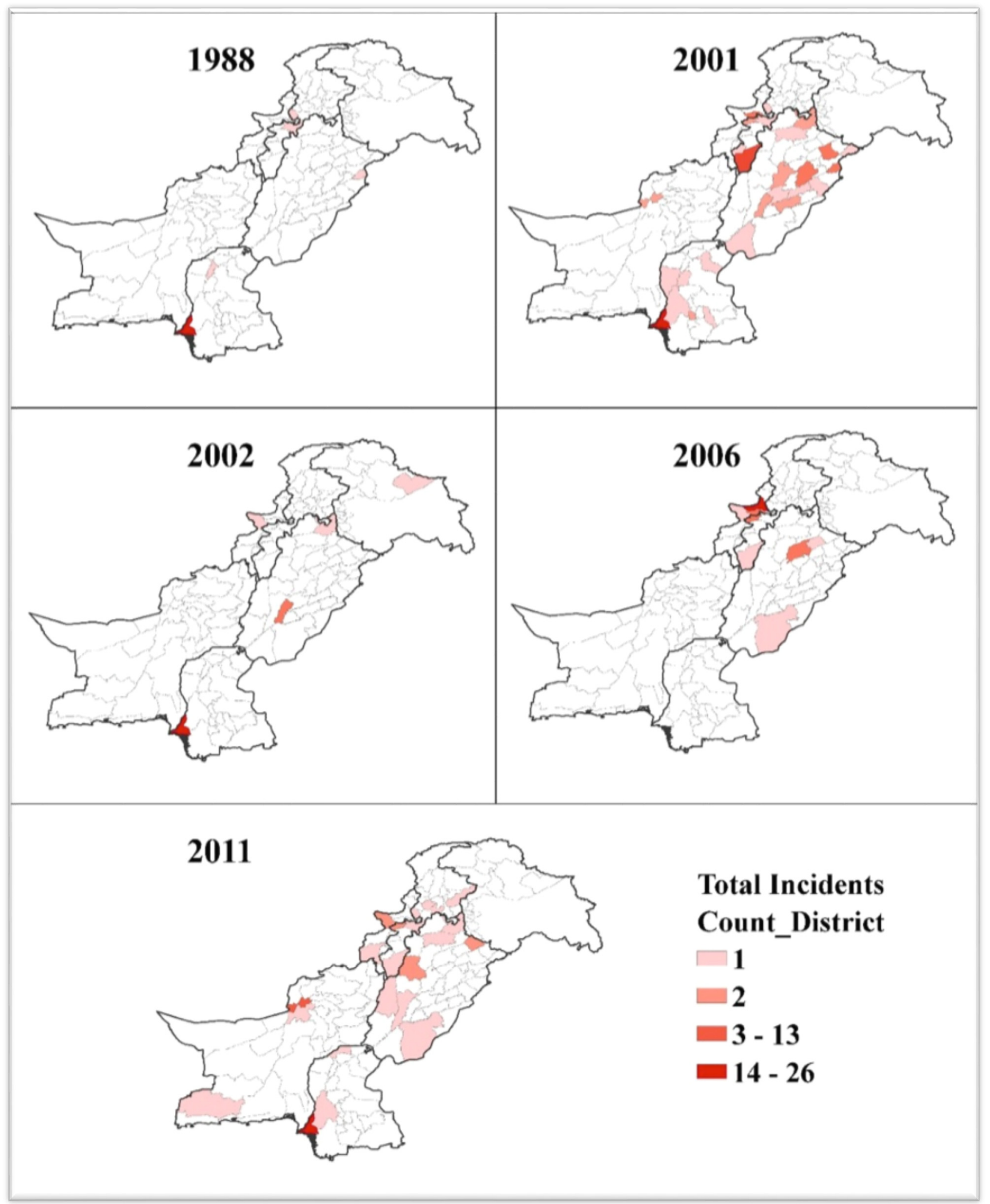

Figure 2. Sectarian Violence in Pakistan-Selected Years. Source: In-house manipulations of BFRS dataset $[29,61]$ by Jesse Turcotte. 


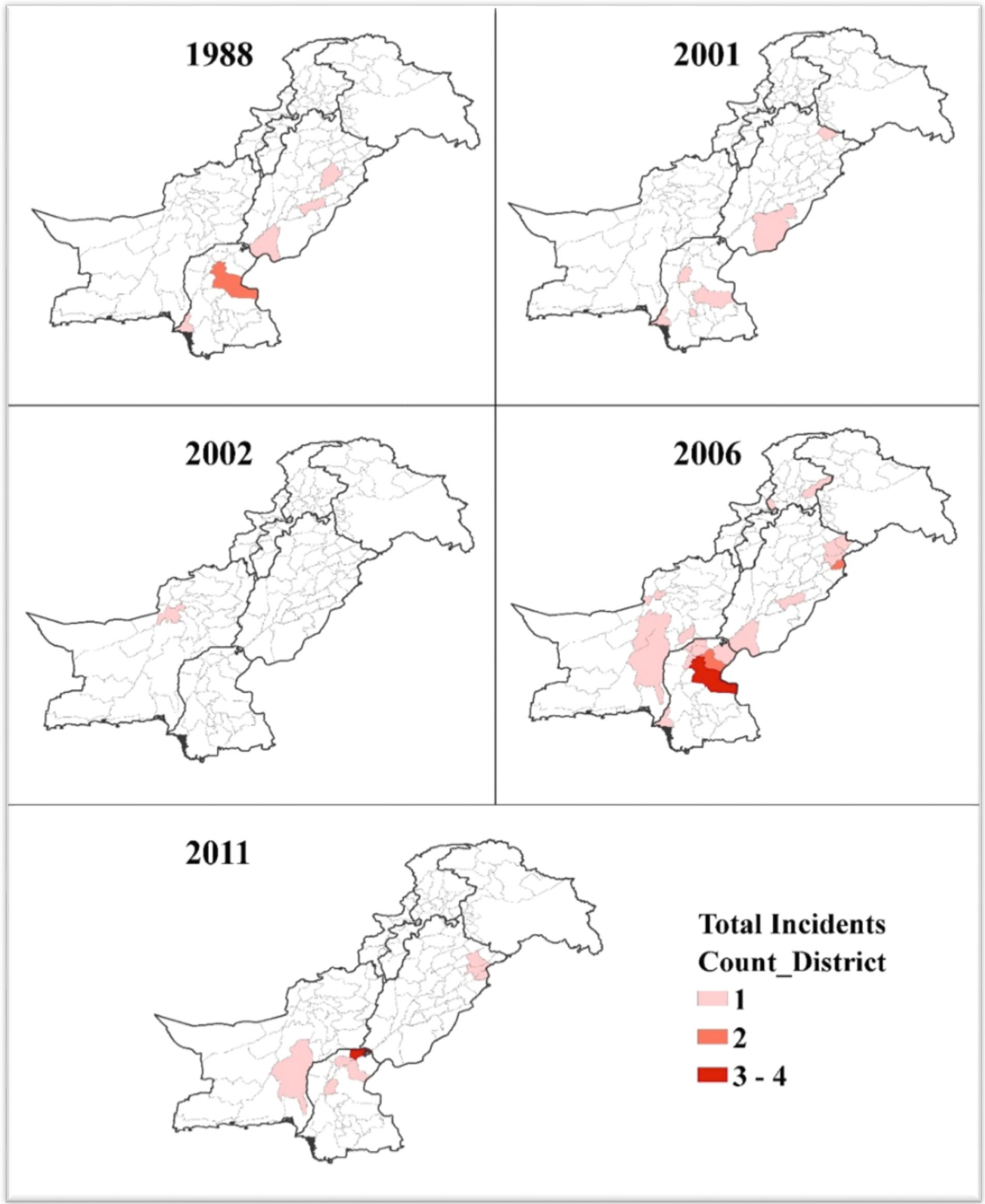

Figure 3. Communal Violence in Pakistan-Selected Years. Source: In-house manipulations of BFRS dataset $[29,61]$ by Jesse Turcotte. 


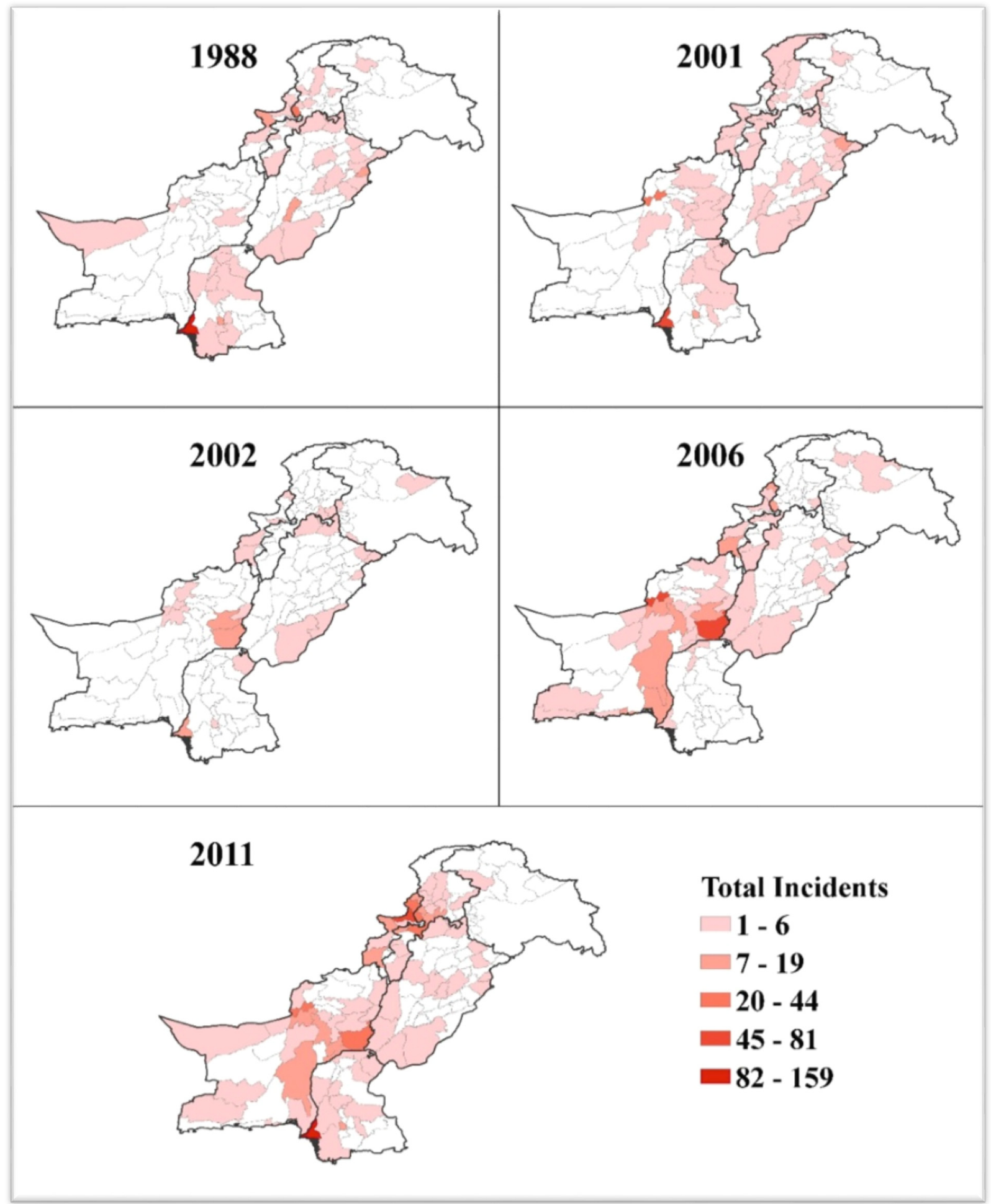

Figure 4. Terrorist Violence in Pakistan-Selected Years. Source: In-house manipulations of BFRS dataset by [29,61] Jesse Turcotte. 

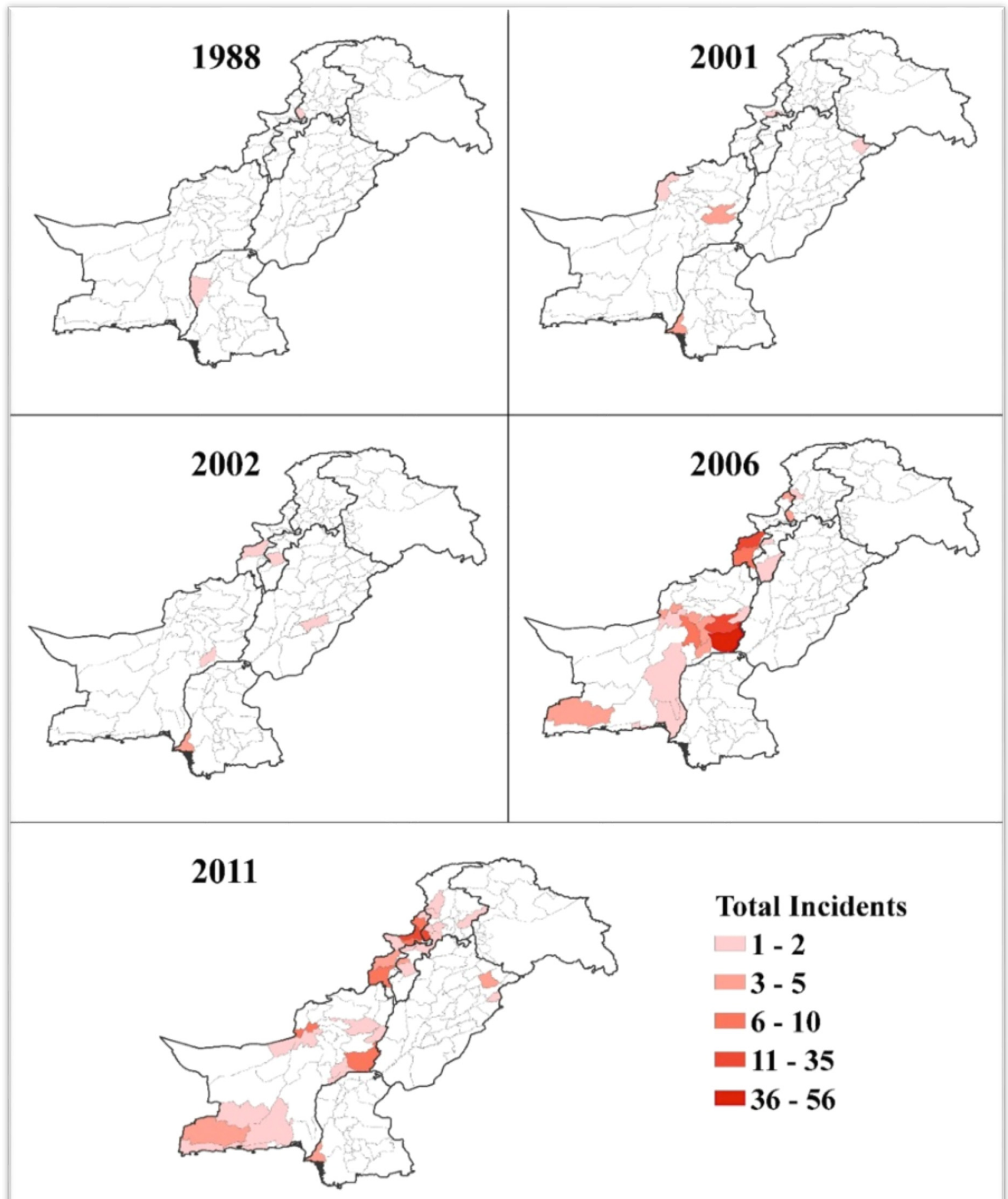

Total Incidents

1 - 2

3 - 5

$6-10$

11 - 35

$=36-56$

Figure 5. Militant/Guerilla Violence in Pakistan-Selected Years. Source: In-house manipulations of BFRS dataset $[29,61]$ by Jesse Turcotte.

\section{Literature Review and Hypotheses}

To formulate testable hypothesis about the determinants of support for sectarian violence in Pakistan, I draw from several policy analytic and scholarly discourses about Islamist militancy. Specifically, I review the literatures that examine potential ties between support for Islamist violence and several 
aspects of Muslim identity politics in Pakistan and other Muslims countries namely: religious practice (piety), support for sharia, and adherence to a particular interpretative tradition or maslak ${ }^{4}$.

\subsection{Piety and Religious Practice}

The "clash of civilizations" thesis advanced by Huntington [26] and Lewis [27] held that tensions between the Muslim world and the West derive from innate conflicts between Islam and Christianity. This provocative assertion galvanized a widening discourse that posited intrinsic ties between Islam and support for Islamist violence 5 . Public intellectuals contributed to this debate with their varied contentions that public support for violence against "the West" is inherently related to Muslim religiosity or faith [63-65] and renowned scholars pursued this line of empirical inquiry as well [66]. Juergensmeyer, for example, employing qualitative case studies concluded that the very theological foundations of religions are soaked in blood and that believers employ violence in elemental aspect of their religious corporate existence $[67,68]$. Weinberg, Pedahzur and Canetti-Nisim, using the Palestinian-Israeli conflict as a case study, argue that it is difficult to "deny that in the Palestinian-Israeli conflict a substantial majority of suicide bombings have been the work of shahids or religious self-martyrs belonging to Hamas and Palestinian Islamic Jihad, two organizations expressing Islamist ideas about the nature of the situation"([69], p. 141). Similarly, Hafez [70], taking the biographies and videos of suicide bombers in Iraq, details how al Qaeda goes to great pains to project the attackers at pious (e.g., frequently engaged in prayer). Taking a somewhat different stance and approach, Wiktorowicz [71], drawing on interviews with recruits in the militant British Islamist group al-Muhajiroun, found that persons who were more religious and engaged with Islam were actually less supportive of and more reistent to al-Muhajiroun's message.

While robust evidence of a link between religiosity and support for militancy is scant, there is mounting countervailing evidence for such a claim (see e.g., [72]). Tessler and Nachtwey [72], in their analysis of public opinion data from Egypt, Kuwait, Palestine, Jordan, and Lebanon, found that frequency of prayer is uncorrelated with attitudes toward conflict with Israel. Clingingsmith, Khwaja, and Kremer found that feelings of Muslim unity and intensified commitment to Islamic orthodoxy among Pakistani pilgrims after performing Hajj were co-extant with expanded tolerance towards non-Muslims [73]. Fair, Malhotra and Shapiro using survey data from Pakistan and an endorsement experiment to measure such support similarly find no ties between support for Islamist militancy and piety [74].

Given that the evidence on the relationship between religious piety and practice on the one hand and support for militant groups on the other is weak or ambiguous, I put forward H1 as a testable hypothesis:

H1: Religious piety and practice is not positively related to support for sectarianism in Pakistan.

4 The first two correspond to Hypotheses 1 and 2 in [62].

5 Advocates of this view often reference "the verse of the sword" in the Quran (Sura 9:5) to justify the link between religious practice and militancy: "Then, when the sacred months have passed, slay the idolaters wherever ye find them, and take them captive, and besiege them, and prepare for them each ambush." 


\subsection{Islamist Politics}

Some scholars who have sought to exposit the determinants of individual support for Islamism and terrorism generally have found no significant positive or, I some cases, negative correlation between the two. Ginges, Hansen and Norenzayan [75] report that while a 2003-2004 survey of Indonesian Muslims did not show an association between religious devotion and prayer frequency and support for suicide attacks, their own research concluded that attendance at religious services did predict support for such attacks among Palestinian Muslims. Similarly, Kaltenthaler, Ceccoli, Gelleny, and Miller [76] analyze survey Pakistanis from 2007 and conclude that there is no correlation between individual beliefs about the extent to which Islam should play a more important and influential role in the world on the one hand and whether they justify terrorist attacks on civilians on the other. Tessler and Nachtwey [72] conclude find that "politicized Islam", measured via responses to four binary questions about the role of Islam in politics, was negatively associated with peaceful attitudes; however, Furia and Lucas [77], analyzing data derived from the 2002 Arab Values Survey, conducted in Egypt, Jordan, Lebanon, Kuwait, Morocco, Saudi Arabia, and the UAE, conclude that Arab Muslims with higher levels of "Islamic consciousness" were no more hostile to Western countries than others. Similarly, Fair, Ramsay, and Kull [78] find no relationship between views on sharia law and support for violence . $^{6}$

Looking across these varied studies and the countries from which they draw, the evidence that ties support for political Islam (variously instrumented) and Islamist violence is not robust. Nonetheless there are several reasons why we might observe a relationship between support for Islamist politics and militancy in Pakistan. First, many avowedly Islamist parties in Pakistan take positions that are explicitly tolerant of some forms of Islamist violence. The two most important Islamist political parties not only vocally support "jihadi" actions but also have direct command and control over key militant groups themselves. For example, Jamaat-e-Islami (JI) not only offers its political support to the Afghan Taliban and opposes military action against the Pakistani Taliban, it also has direct ties to the Hizbul Mujahideen, a so-called "Kashmiri jihadi tanzeem" (organization) that is active in Indian-administered Kashmir. The other key Islamist party is the Deobandi Jamiat Ulema-e-Islami (JUI) vocally supports an array of Deobandi Islamist militant groups, including the Pakistani and Afghan Taliban as well as numerous Kashmiri groups and the SSP/LeJ, and has direct command and control over them $[9,21,31,54,58,83,84]$. Second, these two parties frequently align with other Pakistan-based terrorist organizations such as the

6 Kaltenthaler et al. [76] similarly find that Pakistanis who were more accepting of the imposition of extreme Islamist views (often called "Talibanization") were more likely to believe that attacks on civilians could be justified. There have been other studies that focus upon political beliefs that are not easily classified as "political Islam." Specific political grievances are one of the few reliable determinants of support for militant actions. Chiozza [79] finds that among Muslims in Jordan and Lebanon, the strongest predictor of support for suicide bombings against American forces in Iraq was disaffection towards the American people, not religiosity, and that religiosity was associated with support for attacks only when accompanied by fear for Muslim identity. Similarly, research on Palestinian public opinion towards Israel has repeatedly found that the perception of Israel as posing a threat is strongly associated with support for violence, but that support for political Islam exhibits no association [80-82]. National surveys of Algeria and Jordan in 2002 also showed that while higher levels of religious involvement did not make individuals more likely to approve of terrorist acts against the US, there was a significant relationship between respondents' attitudes towards their government and US foreign policy and their support for terrorism [62]. 
Jamaat-ud-Dawa (previously known as Lashkar-e-Taiba) to form political pressure groups around specific issues (inter alia Pakistan's ties with the United States; closure of the ground lines of control for the US military operations in Afghanistan; opposition to the US-led war in Afghanistan, support for Saudi Arabia's actions in Yemen). It is not unreasonable to assume therefore that a vote for such Islamist parties should be tantamount to supporting the party's jihadi politics ${ }^{7}$. Third, these groups, with their very visible ties to Islamist militancy generally and sectarian militancy in particular, also vocally advocate for the implementation of sharia along the lines of their own particular maslak. Incidentally, disagreement about which form of Sharia should form the basis of Pakistani law leads precludes lasting political alliances in and beyond the ballot box.

Previous empirical work by Fair, Malhotra and Shapiro on Pakistan finds that Pakistanis conceptualize sharia in various ways, with many more seeing sharia as a mechanism for good governance and rule of law rather than punitive measures [86]. Fair, Nugent and Littman, expanding upon those findings and using a larger dataset (described below) that asks more expansive questions of Pakistanis about their beliefs about sharia, find that there are three broad categories into which their beliefs fall: sharia as a form of good governance; sharia as a set of punitive regimes such as hudud ordinances; and sharia as a set of rules that govern women's public role in particular [74]. Presumably, persons who believe sharia is fundamentally about rule of law and good governance should oppose organizations and activities that undermine both. This gives rise to the first of three inter-related hypotheses:

H2a: Support for sharia defined as good governance is negatively related to support for sectarian militancy.

With respect to hudud punishments, many Islamist militant organizations embrace hudud punishments. For example, the Afghan Taliban with whom the SSP collaborated, were in power in Afghanistan and established a sharia government based upon their Deobandi interpretation of Sharia. The Afghan Taliban, both in and out of power, have used hudud ordinances inclusive of stoning adulterers to death, whipping men and women who do not wear "Islamic" dress, punishing men who shave their beards among other physical punishments. The SSP use similar rationale to kill Shia, Barelvis, and Ahmedis as well as non-Muslims arguing variously that they are apostates, blasphemers and kufar (non-believers), all of whom should be killed [12]. It stands to reason that if one rejects hudud notions as a part of sharia, one should also be disinclined to support the militant groups that embrace them. This suggests another hypothesis:

H2b: Support for sharia defined as hudud is positively related to support for sectarian militancy.

Finally, while many militant and non-militant Islamist organizations in Pakistan maintain that women should observe veiling and restrict their presence in public, many women themselves see veiling as a means of expanding their access to the public space while retaining their respectability. Thus for some women, veiling is a liberating mechanism rather than a mechanism of confinement. For other women in

7 While some of the Ahl-e-Hadith ulema in Pakistan have rejected militarized jihad waged by any actor other than the state, Lashkar-e-Taiba (now known as Jamaat ud Dawa) is the only jihadi group in Pakistan that is associated with the Ahl-e-Hadith masalik [85]. 
Pakistan, different kinds of veiling take on different kinds of social signaling altogether, a full discussion of which is beyond this paper ${ }^{8}$. Given these different interpretations about veiling and its contested relationship to various notions of sharia, there are no empirical reasons to suspect that support for aspects of sharia that restrict women should have any correlation with support for terrorism. This gives rise to the third hypothesis in this cluster:

H2c: Support for sharia defined as rules governing women's public role is unrelated to support for sectarian militancy.

\subsection{Maslak and Militancy}

In Pakistan, there are four key Sunni interpretative traditions called masalik (pl. of maslak): Ahl-e-Hadith, Deobandi, Barelvi, and Jamaat-e-Islami. All but Ahl-e-Hadith adherents ascribe to the Hanafi School of Islamic jurisprudence (fiqh). Those of the Ahl-e-Hadith tradition follow no fiqh and refer to themselves accordingly as "ghair muqalid", or one who does not follow any fiqh. In addition to these four Sunni masalik, the fifth maslak encompasses Shia Islam and its variants in Pakistan. While Jamaat-e-Islami is technically supra-sectarian and even denounces sectarianism in its public posturing, JI does align itself politically with the sectarian militant groups and their Deobandi supporters in the JUI among others as noted above and has long supported an array of jihadi causes. The Ahl-e-Hadith maslak also espouses a very sectarian world view. (Note that while Lashkar-e-Taiba follows this school, the terrorist organization is at odds with the mainstream Ahl-e-Hadith ulema) [85]. As noted above, Barelvis have militarized in recent years largely in response to being attacked by Deobandis and even Ahl-e-Hadith adherents. In the past, Shia ulema have aligned with Shia militants who targeted their Sunni Deobandi rivals. These groups are now defunct.

In Pakistan, the production of these different ideological positions is the job of the madaris and the religious scholars they train irrespective of any particular madrassah's maslak ${ }^{9}$. As a fraction of the overall market of full-time enrolled children, less than one percent attends a madrasah full-time. However, many more children and young adults attend a madrasah in addition to their other schools (public or private). One of the dominant functions of madaris is to argue for the legitimacy of each school's maslak. Thus, madaris stand accused of fostering support for sectarianism in Pakistan or at least world views that espouse the superiority of one maslak over another [90,91]. In principle, JI madaris should be an exception as JI claims to repudiate such sectarian divides.

One of the most important function of madaris is the production of ulema (pl. of alim, scholar) and less-accomplished religious leaders who deliver sermons, most notably during Friday prayer and on

8 Among various Muslim women's blogs the issue of the "ho-jabi" is a serious affair. The etymology is a play on words of the original "hejab" and the misogynist epithet of "ho" or "hoe" for a promiscuous woman. A thorough discussion of this social phenomenon is beyond the scope of the paper. But this serious debate among young women is a testament to the varying valence of "hejab" as a not-so-entirely pietic marking. See blog posts variously from [87-89] among numerous others including microblogs on Facebook, Twitter, Instagram, Pinterest and the like.

9 This is not to say that madaris are the only sites of religious education in Pakistan. In fact, Pakistanis receive such education in the public schools as well and many private schools also teach religious and non-religious subjects. In some cases, private schools have even blended the entire madrassah curriculum such that students will have attained the title of alim upon completion of either ten or twelve years of schooling [90]. 
major Muslim holidays. Association with a specific maslak will expose a person to a particular set of sectarian commitments. However, despite the deepening of sectarian divides in Pakistan, not all Pakistanis will readily or openly identify with a particular tradition; survey work indicates that most respondents will prefer to simply say that they are "Ahl-e-Sunnah", or generically "Muslim". Thus, I anticipate that persons who espouse a particular commitment to one of the main Sunni masalik that have been tied to sectarian violence in Pakistan either directly or indirectly (Ahl-e-Hadith, Deobandi) will support sectarian violence while those who identify as "Ahl-e-Sunnah" will be less likely support this violence.This category includes those who espouse Jamaat Islami as well as Barelvi as their maslak of preference. This discussion gives rise to a third testable hypothesis:

H3: Support for sectarian militancy should vary according to the maslak to which the respondent adheres.

\section{Data and Research Methods}

To explore the determinants of support for purveyors of sectarian violence and to test the above-posited hypotheses, I use a dataset originally collected by Fair, Malhotra and Shapiro [91]. That research team fielded a face-to-face survey with a sample of 16,279 people. This included 13,282 interviews in the four main provinces (Punjab, Sindh, Balochistan, and Khyber Pakhuntkhwa), as well as 2997 interviews in six of seven agencies in FATA (Bajaur, Khyber, Kurram, Mohmand, Orakzai, and South Waziristan). The survey was fielded in January and February 2012 in the four main provinces and in April 2012 in FATA.

\section{Analytical Methods}

My dependent variable measures explicit support for one of the key providers of sectarian terrorism in Pakistan, the Sipah-e-Sahaba-e-Pakistan (SSP). As noted above, the SSP not only commits sectarian attacks, it is also involved in communal violence, and it is an important collaborator in violence perpetrated by the Pakistani Taliban, or TTP, and even al-Qaeda. In recent years, its cadres have also left to fight in Syria and Iraq abroad and, domestically, have thrown support to the Islamic State. The question I use for my dependent variable is "How much do you support Sipah-e-Sahaba-e-Pakistan (SSP) and their actions?" Respondents could answer "not at all", "a little", "a moderate amount", "a lot”, or a "great deal".

Per H1, I require a measure that instruments for individual piety. Thus I constructed an index that would measure the intensity of person's religiosity or intensity of religious practice. This index is a straightforward, additive index of the several variables that tap aspects of intensity of, or frequency of, religious practice. To derive this index, I used several questions from the survey noted below.

- Do you attend dars-e-Quran? (if yes, then 1)

- If yes: How many times do you go to dars-e-Quran per week on average? (scaled from 0 to 1)

- How often per week do you pray Namaz? (range scaled from 0 to 1) 
- How many times did you pray Namaz in congregation in the Mosque last Sunday? ${ }^{10}$ (range scaled from 0 to 1 )

- Do you pray “Tahajjud Namaz?” (if yes, 1)

To obtain the respondent score for this index, these five items are summed and then divided by five. The largest possible value for this index is one while the smallest possible value is zero.

Next I developed a cluster of independent variables that instrument for respondent support for different conceptualizations of sharia, derived from the empirical work of Fair, Littman, and Nugent and Fair, Malhotra, and Shapiro find that Pakistanis conceive of sharia in at least three key dimensions: good governance (access to services, minimization of corruption, etc.); "hudud" punishments for crimes (whipping, stoning etc.); and pertaining to women (veiling, presence in public, etc.) $[74,86]$. Following and, at times modifying, their approaches, I use several survey items to construct three additive indices which reflect these different dimensions of sharia. Specifically, the survey asks respondents "Here is a list of things some people say about sharia. Tell us which ones you agree with. Sharia government means:...”. Respondents can agree or disagree with each item presented.

The first sharia index I calculate pertains to respondent's support for the notion that sharia has specific provisions for women. It is derived from the following two survey items:

- A government that restricts women's role in the public (working, attending school, going out in public) (If agree, 1)

- A government that requires women to veil in public. (If agree, 1)

To obtain the value for this index, I add these two measures and divide by two. Thus the maximum possible value of this index is 1 and the smallest value is zero.

The second measure of sharia is an additive index that reflects the degree to which the respondents view sharia essentially in terms of good governance. I derive this index from following four survey items:

- A government that provides basic services such as health facilities, schools, garbage collection, road maintenance. (If agree, 1)

- A government that does not have corruption. (If agree, 1)

- A government that provides personal security. (If agree, 1)

- A government that provides justice through functioning non-corrupt courts. (If agree, 1)

To obtain this index value, I add the values for the above items and then divide by four. This index has a possible of range of zero to one.

The third measure of sharia reflects the degree to which the respondents view sharia essentially in terms of physical punishments. It is derived from the following survey item:

- A government that uses physical punishments (stoning, cutting off of hands, whipping) to make sure people obey the law. (If agree, 1).

This value is zero if the respondent disagrees and 1 if they agree.

10 As is well known, the most important day of prayer is Friday. For many men, they only got to a mosque on a Friday. For this reasons, we deliberately chose an "off day" to measure prayer attendance in a mosque. In Pakistan, few women are encouraged to prayer in a mosque and thus they do their prayers at home. 
The third set of independent variables refers to the maslak of the respondent. Due to fears of respondent social desirability bias, Fair et al. [92] do not ask respondents directly about the maslak they embrace. Rather, they ask this indirectly by querying the respondent "If a child in your house were to study hifz-e-Quran or nazira, what kind of madrassah or school would you like them to attend?" (Hifz-e-Quran is the memorization of the Quran while Nazira is learning to recite the Quran properly). I similarly use this question to instrument for respondent maslak. In this open-ended question, respondents gave the following answers "Sunni" (which includes Jamaat Islami and Barelvi), "Deobandi", "Ahl-e-hadith", "Shia", "Non-Muslim", and "Don't Know".

In addition to these independent variables, following Shafiq and Sinno [93], I include several control variables including marital status (single/never married, married, divorced, widowed), age group (18-29, 30-49, 50+), educational attainment (less than primary, primary (6th grade), middle (8th grade) matriculate (10th grade), higher education (above 10th grade)), and income quartiles. In addition, I include ethnicity due to the observed geographical patterns in the kinds of violence evidenced and documented in this paper. In Table 2, I present the summary statistics for the dependent, independent, and control variables.

To conduct the analysis, I ran ordinary least squares regression on the dependent variable that captures support for SSP and its actions, using the above noted list of variables for Muslim respondents only. I categorized respondent as "non-Muslim" if they indicated that they were non-Muslim when asked about the kind of madrassah they would use for their children. If respondents did not answer the question or said "did not know," their responses were coded as "missing". To capture any district-level characteristics for which I cannot control directly, I ran this model both with and without district fixed-effects. Because the original survey sample was drawn at the level of the Primary Sampling Unit (PSU), standard errors are clustered at the PSU (for details about the survey execution, see discussion in $[28,74])$. In Table 2, I indicate with an “*” the reference group, within a particular variable cluster, which I used as the "omitted group" in the regression.

Table 2. Summary Statistics of Dependent and Independent Variables.

\begin{tabular}{llll}
\hline & Categories & Frequency & Percentage \\
\hline Dependent Variable & & & \\
& Not at all & 6176 & $37.9 \%$ \\
& A little & 2238 & $13.7 \%$ \\
How much do you support Sipah-e-Sahaba-e- & A moderate amount & 2521 & $15.5 \%$ \\
Pakistan (SSP) and their actions? & A lot & 1287 & $7.9 \%$ \\
& A great deal & 1268 & $7.8 \%$ \\
Total & No answer & 2789 & $17.1 \%$ \\
\hline
\end{tabular}


Table 2. Cont.

\begin{tabular}{|c|c|c|c|}
\hline & Categories & Frequency & Percentage \\
\hline \multicolumn{4}{|l|}{ Independent variables } \\
\hline \multirow{26}{*}{ Piety Index (0.00-1.00) } & 0.00 & 912 & $5.60 \%$ \\
\hline & 0.04 & 1121 & $6.89 \%$ \\
\hline & 0.08 & 694 & $4.26 \%$ \\
\hline & 0.12 & 543 & $3.34 \%$ \\
\hline & 0.16 & 721 & $4.43 \%$ \\
\hline & 0.2 & 1332 & $8.18 \%$ \\
\hline & 0.24 & 480 & $2.95 \%$ \\
\hline & 0.28 & 1345 & $8.26 \%$ \\
\hline & 0.32 & 675 & $4.15 \%$ \\
\hline & 0.36 & 742 & $4.56 \%$ \\
\hline & 0.4 & 1152 & $7.08 \%$ \\
\hline & 0.44 & 1123 & $6.90 \%$ \\
\hline & 0.48 & 714 & $4.39 \%$ \\
\hline & 0.52 & 603 & $3.70 \%$ \\
\hline & 0.56 & 647 & $3.97 \%$ \\
\hline & 0.6 & 564 & $3.46 \%$ \\
\hline & 0.64 & 656 & $4.03 \%$ \\
\hline & 0.68 & 396 & $2.43 \%$ \\
\hline & 0.72 & 404 & $2.48 \%$ \\
\hline & 0.76 & 635 & $3.90 \%$ \\
\hline & 0.8 & 107 & $0.66 \%$ \\
\hline & 0.84 & 259 & $1.59 \%$ \\
\hline & 0.88 & 141 & $0.87 \%$ \\
\hline & 0.92 & 92 & $0.57 \%$ \\
\hline & 0.96 & 220 & $1.35 \%$ \\
\hline & 1.00 & 1 & $0.01 \%$ \\
\hline \multirow[t]{3}{*}{ Total } & & 16,279 & $100 \%$ \\
\hline & 0.00 & 415 & $2.55 \%$ \\
\hline & 0.25 & 600 & $3.69 \%$ \\
\hline \multirow[t]{3}{*}{ Sharia Good Governance Index (0.00-1.00) } & 0.5 & 1164 & $7.15 \%$ \\
\hline & 0.75 & 2925 & $17.97 \%$ \\
\hline & 1.00 & 11,175 & $68.65 \%$ \\
\hline Total & & 16,279 & $100 \%$ \\
\hline \multirow{2}{*}{ Sharia Hudud Index (0.00-1.00) } & 0.00 & 6913 & $42.47 \%$ \\
\hline & 1.00 & 9366 & $57.53 \%$ \\
\hline Total & & 16,279 & $100 \%$ \\
\hline
\end{tabular}


Table 2. Cont.

\begin{tabular}{|c|c|c|c|}
\hline & Categories & Frequency & Percentage \\
\hline \multirow{3}{*}{ Sharia Women Index } & 0 & 3547 & $21.79 \%$ \\
\hline & 0.5 & 6622 & $40.68 \%$ \\
\hline & 1 & 6110 & $37.53 \%$ \\
\hline \multirow[t]{2}{*}{ Total } & & 16,279 & $100 \%$ \\
\hline & Shia * & 601 & $3.69 \%$ \\
\hline \multirow{5}{*}{ Maslak: Type of Madrassah } & Sunni & 7394 & $45.42 \%$ \\
\hline & Deobandi & 5928 & $36.42 \%$ \\
\hline & Ahl-hadith & 585 & $3.59 \%$ \\
\hline & Non Muslim & 384 & $2.36 \%$ \\
\hline & Don't know/No response & 1387 & $8.52 \%$ \\
\hline Total & & 16,279 & $100 \%$ \\
\hline \multicolumn{4}{|l|}{ Control Variables } \\
\hline \multirow{7}{*}{ Ethnicity } & Other * & 818 & $5.03 \%$ \\
\hline & Punjabi & 5325 & $32.71 \%$ \\
\hline & Muhajiir & 1073 & $6.59 \%$ \\
\hline & Pashtun & 5718 & $35.13 \%$ \\
\hline & Sindhi & 1673 & $10.28 \%$ \\
\hline & Baloch & 1566 & $9.62 \%$ \\
\hline & No response/don't know & 106 & $0.65 \%$ \\
\hline \multirow[t]{3}{*}{ Total } & & 16,279 & $100 \%$ \\
\hline & Married & 12,481 & $76.67 \%$ \\
\hline & Divorced & 38 & $0.23 \%$ \\
\hline \multirow[t]{3}{*}{ Marital Status } & Widowed & 424 & $2.33 \%$ \\
\hline & Single/never married $*$ & 3292 & $20.22 \%$ \\
\hline & Don't know/ no answer & 44 & $0.27 \%$ \\
\hline \multirow[t]{3}{*}{ Total } & & 16,279 & $100 \%$ \\
\hline & Less than Primary * & 6354 & $39.03 \%$ \\
\hline & Primary & 1951 & $11.99 \%$ \\
\hline \multirow{4}{*}{ Level of Education } & Middle & 2189 & $13.45 \%$ \\
\hline & Matriculate & 2875 & $17.66 \%$ \\
\hline & Higher Education & 2732 & $16.78 \%$ \\
\hline & Don't know/no response & 178 & $1.09 \%$ \\
\hline Total & & 16,279 & $100 \%$ \\
\hline
\end{tabular}


Table 2. Cont.

\begin{tabular}{llll}
\hline & Categories & Frequency & Percentage \\
\hline \multirow{3}{*}{ Age Group } & $18-29 *$ & 5945 & $36.52 \%$ \\
& $30-49$ & 7896 & $48.50 \%$ \\
Total & $50+$ & 2396 & $14.7 \%$ \\
& Don't know/no response & 42 & $0.26 \%$ \\
& & 16,279 & $100 \%$ \\
Income Quartiles & First quartile * & 5640 & $34.65 \%$ \\
& Second quartile & 4272 & $26.24 \%$ \\
& Third quartile & 1974 & $12.13 \%$ \\
Total & Fourth quartile & 3162 & $19.42 \%$ \\
\hline
\end{tabular}

Note: * denotes regression reference level.

\section{Discussion of Regression Results}

As the regression results in Table 3 show, many of the independent variables are significant in the full model (without fixed effects). For example, with respect to $\mathrm{H} 1$ which posits ties between piety and support for sectarianism, I find that increased piety is significantly and positively associated with higher support for sectarianism contrary to what I had had hypothesized based upon the existing literature. Turning to respondent perceptions of sharia on the one hand and support for sectarian militancy on the other, I find mild support for $\mathrm{H} 2 \mathrm{a}$ that respondents who believe sharia implies good governance are less approving of sectarian militancy. Consistent with $\mathrm{H} 2 \mathrm{~b}$, I also find that respondents who interpret sharia in terms of hudud offences exhibit greater support for sectarian militancy. With respect to H2c, I find that those who interpret sharia as imposing strictures on women's public life are less supportive of sectarianism. However, all of these results dissipate when I control for district fixed effects. In other words, district-level characteristics for which I cannot explicitly control for in this model "absorb" the effects of these independent variables for piety and interpretations of sharia.

The third hypothesis concerns the respondents' professed maslak. It turns out that a person's maslak is a far more stable predictor of support for various aspects of sharia or evidenced piety. Relative to those who are Shia, the reference category in this regression, those who identify with one of the Sunni masalik are strongly associated with support for sectarian militancy. Contrary to my expectations, even those who simply identify as "Sunni-in contrast to "Deobandi" or "Ahl-e-Hadith" - are more inclined to support sectarian militancy. These results persist as significant and positive even when district fixed effects are included. This outcome tends to support the findings of Fair (2008) and Ali (2009) that sectarianism in Pakistan is tightly related to the production of identities associated with adherence to particular masalik $[83,90]$.

One of the primary institutions that produces these identities is the madrasah which educates Pakistan's religious scholars and preachers who in turn disseminate and reproduce these ideologies and identities within institutions tied to these masalik (e.g., mosques, madaris, etc.). Unfortunately, Pakistan's madaris have fiercely fought off any sort of reform that could possibly attenuate the sectarian 
worldviews that they generate and sustain far and beyond the numbers of students who pass through their doors. Madaris, of course, are not the only institutions that reproduce ties to a particular masalak and the sectarian outlooks they create and reinforce. Other sources of sectarian influence include, inter alia: family and social networks [94]; public schools [95]; civil society organizations which have been inflected by Islamic movements [96]; proselytization efforts that many Islamist and Islamic groups encourage [97]; Islamic revival organizations such as al Huda [98]; Islamist political parties [97]; religious television and radio programming [99]; internet-based religious content and programming [99]; as well as religious print materials. Unfortunately, it is beyond the data used to here to identify the various sources that contribute to a respondent's embrace of a particular maslak and the sectarian worldviews that identification seems to inculcate.

Most of the control variables (including marital status, education, income and age) are not significant when I control for district characteristics. There is one important exception: those in the oldest age category (50 years and older) are significantly less likely to support sectarian militancy. In many cases ethnicity is significant in explaining variation support for sectarian violence. Controlling for all other factors noted above and relative to those who identified their ethnicity as "other" (e.g., Kashmiri), Punjabis, Sindhis, and Baloch are less likely to support sectarianism in both models. This is likely due to the fact that Punjab, Sindh and Balochistan have experienced considerable amounts of violence perpetrated by Islamists militants, as Figures 1 and 2 attest.

Table 3. Regression Results (How much do you support Sipah-e-Sahaba-e-Pakistan (SSP) and their actions?

\begin{tabular}{lll}
\hline & No District Fixed Effects & With District Fixed Effects \\
\hline Independent Variables & & \\
piety_ind_rounded & $0.400(3.84) * *$ & $0.174(1.82)$ \\
sharia_gg_ind & $-0.457(-4.61) * *$ & $-0.172(-1.74)$ \\
sharia_h_ind & $0.125(2.57) *$ & $-0.026(-0.54)$ \\
sharia_wom_ind & $-0.223(-3.88) * *$ & $-0.079(-1.54)$ \\
madrasa_sunni & $0.754(8.94) * *$ & $0.516(4.23) * *$ \\
madrasa_deobandi & $0.953(10.59) * *$ & $0.708(5.38) * *$ \\
madrasa_ahl_e_hadis & $0.823(6.16) * *$ & $0.646(4.04) * *$ \\
Control Variables & & \\
maritalstatus_married & $0.079(1.78)$ & $0.092(2.29) *$ \\
maritalstatus_divorced & $0.200(0.57)$ & $0.233(0.73)$ \\
maritalstatus_widowed & $0.140(1.32)$ & $0.132(1.33)$ \\
ethnicity_punjabi & $-0.283(-2.45) *$ & $-0.294(-2.27) *$ \\
Control Variables & & $-0.064(-1.46)$ \\
ethnicity_muhajir & $-0.560(-4.30) * *$ & $-0.129(-0.94)$ \\
ethnicity_pashtun & $-0.153(-1.29)$ & $-0.162(-1.13)$ \\
ethnicity_sindhi & $-0.691(-5.40) * *$ & $-0.492(-3.17)^{* *}$ \\
ethnicity_baloch & $-0.537(-3.81) * *$ & $-0.343(-2.16)^{*}$ \\
educ_primary & $-0.098(-2.04) *$ & -0.064 \\
\hline & & \\
\hline
\end{tabular}


Table 3. Cont.

\begin{tabular}{lll}
\hline & No District Fixed Effects & With District Fixed Effects \\
\hline educ_middle & $-0.070(-1.44)$ & $-0.039(-0.90)$ \\
educ_matric & $-0.084(-1.67)$ & $-0.036(-0.77)$ \\
educ_higher & $-0.158(-2.97) * *$ & $-0.084(-1.70)$ \\
age_30to49 & $-0.062(-1.71)$ & $-0.041(-1.27)$ \\
age_50plus & $-0.296(-5.85) * *$ & $-0.218(-4.74) * *$ \\
quartile_second & $0.008(0.20)$ & $-0.012(-0.34)$ \\
quartile_third & $0.011(0.20)$ & $-0.035(-0.72)$ \\
quartile_fourth & $0.072(1.45)$ & $-0.031(-0.64)$ \\
cons & $1.049(5.84) * *$ & $1.022(5.21) * *$ \\
R2 & 0.08 & 0.21 \\
$\mathrm{~N}$ & 11,601 & 11,601 \\
\hline \multicolumn{2}{c}{ Notes: $* p<0.05 ; * * p<0.01}$.
\end{tabular}

\section{Conclusions and Implications}

While analysts and scholars of security studies typically view Pakistan as a perpetrator and exporter of Islamist terrorism; this analysis shows that Pakistanis are perhaps the largest group of victims of these Pakistan-based groups apart from the Afghans; whose country has been the object of considerable Pakistani predations from the 1950s onward [20,100]. Unfortunately; the roots of these groups savaging Pakistanis are predominantly domestic and tied to the state's security policies towards India and Afghanistan [14]. After all; there would be no Pakistan Taliban had there been no Afghan Taliban and the myriad other Deobandi groups that the state has supported has supported from the mid-1970s. Alarmingly; even Pakistan's sectarian groups; such as SSP/LeJ; have been important allies of segments of the state at various times.

The durability of these Deobandi sectarian groups should motivate the Pakistani government to rethink its policies not only due to the toll they have exacted from Pakistanis, but because Pakistan's sectarian groups are likely to become ever more enmeshed in contemporary sectarian conflicts far beyond South Asia, as Saudi Arabia and Iran continue to carry out their sectarian proxy wars in Bahrain, Yemen, Syria, Iraq and elsewhere. Given that sectarianism in Pakistan has its origins from Iranian and Arab Gulf State sectarian competition in late 1970s, Pakistan should be deeply concerned. Indeed, it seems that the challenges of sectarianism in Pakistan are poised to deepen rather than retract given these developing realities and the insouciance and ambivalence that Pakistan's civilian and military entities exhibit towards the purveyors of sectarian violence.

Pakistan's will to eradicate sectarian militancy is constrained by the overlapping nature of the various militant groups and their membership. For example, Pakistan cannot tackle the Pakistani Taliban and their sectarian collaborators while it still fosters the Afghan Taliban and other Deobandi groups, such as the Jaish-e-Mohammad, that operate in India. Even if the state had the will to counter all forms of Islamist militancy including those that have external utility in Afghanistan and India, the evidence is not encouraging that Pakistan has the capacity. Pakistan's law enforcement institutions - including the judiciary-are 
woefully ill prepared for this task. All of Pakistan's rule of law institutions are riven with corruption and have suffered neglect at the hands of federal and provincial governments for decades $[101,102]$.

The survey data analyzed here offer little hope either. The most consistent and positive predictors of support for sectarian violence are sectarian commitments as expressed through their maslak. These characteristics - unlike education levels or poverty — cannot be easily influenced over time either by Pakistan policy actions or by international actors. More challenging yet, commitments to a particular maslak and the sectarian views they encourage are deeply rooted to multiple facets of Pakistan's educational landscape as well as social and cultural practices. However, the good news is that most ethnic groups are less likely to support sectarian violence relative to those who identified their ethnicity as "other." It is beyond this paper and the data analyzed here to exposit this mechanism. It is possible that Punjabis, Sindhis and Baloch may oppose sectarian violence most because their provinces have witnesses much of this kind of violence. However, in recent years, so has KPK and Pashtun ethnicity is not a significant predictor of support. Understanding the drivers of these ethnicity effects may offer some future promise in dampening support for this violence if the Pakistani state is ever motivated to do so. It seems that Pakistan is going to continue to bleed for the foreseeable future.

\section{Acknowledgments}

I am thankful to Jessica Bluestein and Ali Hamza who did the statistical programming for this project and Jesse Turcotte, who did the geo-coded mapping. I am also thankful to Georgetown's School of Foreign Service and the Security Studies program which have supported this effort generously by funding the work of Bluestein and Hamza. The original survey data used here were collected with funding from the US Embassy in Islamabad, Public Affairs Section. I am also grateful to my collaborators on related work, in alphabetical order: Graeme Blair, Patrick Kuhn, Rebecca Littman, Neil Malhotra, Elizabeth Nugent, and Jacob Shapiro.

\section{Conflicts of Interest}

The author declares no conflict of interest. However the survey data used here were collected under a grant from the US Embassy in Islamabad (Pakistan), Department of Public Affairs.

\section{References}

1. US Central Intelligence Agency. “The World Factbook: Pakistan.” 24 June 2015. Available online: https://www.cia.gov/library/publications/the-world-factbook/geos/pk.html (accessed on 1 September 2015).

2. US Central Intelligence Agency. "The World Factbook: Iran.” 24 August 2015. Available online: https://www.cia.gov/library/publications/the-world-factbook/geos/ir.html (accessed on 1 September 2015).

3. US Central Intelligence Agency. “The World Factbook: Saudi Arabia.” 26 August 2015. Available online: https://www.cia.gov/library/publications/the-world-factbook/geos/sa.html (accessed on 1 September 2015). 
4. US Central Intelligence Agency. "The World Factbook: Egypt.” 25 August 2015. Available online: https://www.cia.gov/library/publications/the-world-factbook/geos/eg.html (accessed on 1 September 2015).

5. Koblentz, Gregory D. "Strategic Stability in the Second Nuclear Age." Council on Foreign Relations, 19 November 2014. Available online: http://www.cfr.org/nonproliferation-arms-controland-disarmament/strategic-stability-second-nuclear-age/p33809\# (accessed on 31 August 2015).

6. Sankaran, Jaganath. "Pakistan's Battlefield Nuclear Policy: A Risky Solution to an Exaggerated Threat." International Security 39 (2015): 118-51.

7. Fair, C. Christine. Fighting to the End: The Pakistan Army's Way of War. New York: Oxford University Press, 2014.

8. Nawaz, Shuja. “The First Kashmir War Revisited.” India Review 7 (2008): 115-54.

9. Swami, Praveen. India, Pakistan and the Secret Jihad: The Covert War in Kashmir, 1947-2004. London: Routledge, 2007.

10. Hussain, Irfan. "In the name of faith." The Dawn, 27 September 2008. Available online: http://www.dawn.com/news/421131/in-the-name-of-faith (accessed on 31 August 2015).

11. Tanveer, Rana. "In broad daylight: Ahmadi leader gunned down in Gujranwala." Express Tribune, 28 December 2014. Available online: http://tribune.com.pk/story/813329/in-broad-daylightahmadi-leader-gunned-down-in-gujranwala/3 (accessed on 1 September 2015).

12. Lashkar-e-Jhangvi. "Shia Wajib Ul Qatal Kiyon (Why Are Shia Deserving of Being Killed)?" December 2008. Idara-e-Inteqam-e-Haq. Available online: http:/www.mediafire.com/download/ oiv665tqtvsfve2/Shia+Wajib+U1+Qatal+Kiyon.pdf (accessed on 3 September 2015).

13. Ispahani, Farahnaz. "Cleansing Pakistan of Minorities." Current Trends in Islamist Ideology, 31 July 2013. Available online: http://www.hudson.org/research/9781-cleansing-pakistan-of-minorities (accessed on 1 September 2015).

14. Qazi, Shehzad H. "Rebels of the frontier: origins, organization, and recruitment of the Pakistani Taliban.” Small Wars \& Insurgencies 22 (2011): 574-601.

15. Abou Zahab, Mariam. "The Regional Dimensions of Sectarian Conflict in Pakistan." In Pakistan: Nationalism Without a Nation. Edited by Christophe Jaffrelot. London: Zed Books, 2002, pp. 115-30.

16. Abou Zahab, Mariam, Olivier Roy. Islamist Networks: The Afghan-Pakistan Connection. London: C. Hurst and Co., 2004.

17. Nasr, Seyyed Vali Reza. "The Rise of Sunni Militancy in Pakistan: The Changing Role of Islamism and the Ulama in Society and Politics." Modern Asian Studies 34 (2000): 139-80.

18. Zaman, Muhammad Qasim. "Sectarianism in Pakistan: The Radicalization of Shi'i and Sunni Identities." Modern Asian Studies 32 (1998): 689-716.

19. Kfir, Isaac. "Sectarian Violence and Social Group Identity in Pakistan." Studies in Conflict \& Terrorism 37 (2014): 457-72.

20. Hussain, Rizwan. Pakistan and the Emergence of Islamic Militancy in Afghanistan. Burlington: Ashgate, 2005.

21. Fair, C. Christine. "Militant recruitment in Pakistan: Implications for Al-Qai'da and Other Organizations." Studies in Conflict and Terrorism 27 (2004): 489-504.

22. Haqqani, Husain. Pakistan: Between Mosque and Military. Washington: CEIP, 2005. 
23. Mehsud, Saud, and Mubasher Bukhari. "Pakistan Taliban Splinter Group Vows Allegiance to Islamic State.” Reuters, 18 November 2014. Available online: http://www.reuters.com/article/ 2014/11/18/us-pakistan-militants-is-idUSKCNOJ20YQ20141118 (accessed on 1 September 2015).

24. Ur Rehman, Zia. "Pakistani Fighters Joining the War in Syria." Combating Terrorism Center, 9 September 2013. Available online: https:/www.ctc.usma.edu/posts/pakistani-fighters-joining-thewar-in-syria (accessed on 9 September 2015).

25. Al-Salhy, Suadad. "Syria War Widens Rift Between Shi' ite Clergy in Iraq, Iran." Reuters, 20 July 2013. Available online: http://www.reuters.com/article/2013/07/20/us-iraq-politics-syriaidUSBRE96J04120130720 (accessed on 1 September 2015).

26. Huntington, Samuel P. The Clash of Civilizations and the Remaking of the World Order. New York: Simon \& Schuster, 1996.

27. Lewis, Bernard. "The roots of Muslim rage: Why so many Muslims deeply resent the West and why their bitterness will not be easily mollified." Atlantic Monthly 266 (1990): 47-60.

28. Fair, C. Christine, Rebecca Littman, Neil Malhotra, and Jacob N. Shapiro. "Relative Poverty, Perceived Violence, and Support for Militant Politics: Evidence from Pakistan.” 2013. Available online: http://www.princeton.edu/ jns/papers/FLMS_2013_Poverty_Violence_Support_for_Militancy.pdf (accessed on 1 September 2015).

29. Bueno de Mesquita, E., C. Christine Fair, Jenna Jordan, Rasul Bakhsh Rais, and Jacob N. Shapiro. "The BFRS Political Violence in Pakistan Dataset." 2013. Available online: https:// webspace.princeton.edu/users/esocweb/ESOC\%20website\%20publications/BFJRS_2013_PK_D ata_v10.pdf (accessed on 31 August 2015).

30. Sarkees, Meredith Reid, and Phil Schafer. "The Correlates of War Data on War: An Update to 1997." Conflict Management and Peace Science 18 (2000): 123-44.

31. Fair, C. Christine. "The Militant Challenge in Pakistan." Asia Policy 11 (2011): 105-37.

32. Mahsud, Mansur Khan. "The Battle for Pakistan Militancy and Conflict in South Waziristan." New America Foundation, 2010. Available online: http:/www.operationspaix.net/DATA/DOCUMENT/ 4799 v $\sim$ The_Battle_for_Pakistan__Militancy_and_Conflict_in_South_Waziristan.pdf (accessed on 1 September 2015).

33. Rafiq, Arif. Sunni Deobandi-Shi i Sectarian Violence in Pakistan (Explaining the Resurgence Since 2007). Washington: Middle East Institute, 2014. Available online: http://www.mei.edu/ sites/default/files/publications/Arif\%20Rafiq\%20report.pdf (accessed on 1 September 2015).

34. Roggio, Bill. "Suicide Bomber Kills 60 at Mosque in Pakistan's Northwest." Long War Journal, 5 November 2010. Available online: http://www.longwarjournal.org/archives/2010/11/suicide bomber_kills_40.php (accessed on 1 September 2015).

35. Mir, Amir. True Face of the Jehadis. Lahore: Mashall, 2004.

36. Fair, C. Christine, and Seth G. Jones. "Pakistan's War Within." Survival 51 (2010): 161-88.

37. BBC.com. "The Afghan-Pakistan militant nexus." 5 February 2013. Available online: http:// www.bbc.com/news/world-asia-21338263 (accessed on 31 August 2015).

38. Pak Institute for Peace Studies. PIPS Security Report 2009. Islamabad: PIPS, 2009. Available online: http://san-pips.com/download.php?f=29.pdf (accessed on 1 September 2015).

39. New York Times. "Hakimullah Mehsud." 29 April 2010. Available online: http:// topics.nytimes.com/topics/reference/timestopics/people/m/hakimullah_mehsud/index.html (accessed on 1 September 2015). 
40. PBS Newshour. "Pakistan Blast Sharpens Concern on Taliban.” PBS Newshour, 1 April 2010. Available online: http://www.pbs.org/newshour/bb/military-jan-june10-pakistan_01-01/ (accessed on 1 September 2015).

41. Siddique, Qandeel. "The Syria Conflict and Its Impact on Pakistan." 2014. Available online: http://strategiskanalyse.no/Publikasjoner\%202014/2014-02-20_SISA15_The-Syria-ConflictPak_QS.pdf (accessed on 1 September 2015).

42. Tohid, Owais. "In Pakistan, Militant Attacks on Sufi Shrines on the Rise." Christian Science Monitor, 5 November 2010. Available online: http://www.csmonitor.com/World/Asia-South-Central/ 2010/1105/In-Pakistan-militant-attacks-on-Sufi-shrines-on-the-rise (accessed on 1 September 2015).

43. Tavernise, Sabrina. "Suicide Bombers Strike Sufi Shrine in Pakistan." The New York Times, 1 July 2010. Available online: http://www.nytimes.com/2010/07/02/world/asia/02pstan.html (accessed on 1 September 2015).

44. Gul, Imtiaz. The Al Qaeda Connection: The Taliban and Terror in Pakistan's Tribal Areas. London: Penguin, 2009.

45. Masood, Salman, and Waqar Gillani. "Blast at Pakistan Shrine Kills Dozens." The New York Times, 3 April 2010. Available online: http://www.nytimes.com/2011/04/04/world/asia/ 04pakistan.html?partner=rss\&emc $=$ rss (accessed on 31 August 2015).

46. Karimjee, Mariya. "Crocodile Tears: Taliban Attacks on Sufi Shrines Lead to Unlikely Victims." Al Jazeera, 15 December 2014. Available online: http://america.aljazeera.com/articles/2014/ 12/15/sufi-shrine-crocodiles.html (accessed on 31 August 2015).

47. Hassan, Syed Raza. “Gunmen kills 43 in bus attack in Pakistan's Karachi.” Reuters, 13 May 2015. Available online: http://www.reuters.com/article/2015/05/13/us-pakistan-attack-idUSKBN0NY 0FH20150513 (accessed on 1 September 2015).

48. Bin Perwaiz, Salis. "Jundullah, LeJ worked together to target SSP Farooq Awan." The News, 27 September 2014. Available online: http://www.thenews.com.pk/Todays-News-4-275158-JundullahLeJ-worked-together-to-targe (accessed on 31 August 2015).

49. Siddique, Qandeel. "Tehrik-e-Taliban Pakistan: An Attempt to Deconstruct the Umbrella Organization and the Reasons for Its Growth in Pakistan's North-West.” 2010. Available online: http://diisinfo.dk/graphics/Publications/Reports2010/RP2010-12-Tehrik-e-Taliban_web.pdf (accessed on 1 September 2015).

50. Craig, Tim. "Drone kills Taliban chief Hakimullah Mehsud; Pakistan accuses U.S. of derailing peace talks." Washington Post, 2 November 2013. Available online: http://www.washingtonpost.com/ world/asia_pacific/pakistani-official-accuses-us-of-sabotage-as-drone-targets-taliban-leaders-innorthwest/2013/11/01/1463d0c2-431d-11e3-b028-de922d7a3f47_story.html (accessed on 31 August 2015).

51. Hashim, Asad. "The iron fist of Maulana Fazlullah." Al Jazeera, 8 November 2013. Available online: http://www.aljazeera.com/indepth/features/2013/11/iron-fist-maulana-fazlullah20131171538269715.html (accessed on 31 September 2015).

52. Khan, Zia. "Pakistani Spies Trace Fazlullah to Kunar Province." The Express Tribune, 26 July 2010. Available online: http://tribune.com.pk/story/31093/pakistani-spies-trace-fazlullah-tokunar-province/ (accessed on 31 August 2015). 
53. Nazish, Kiran. “The Islamic State's Potential Recruits in Pakistan.” The Diplomat, 3 October 2014. Available online: http://thediplomat.com/2014/10/the-islamic-state-arrives-in-pakistan/ (accessed on 1 September 2015).

54. Fair, C. Christine. "Militant Recruitment in Pakistan: A New Look at the Militancy-Madrasah Connection." Asia Policy 4 (2007): 107-34.

55. Nasr, Seyyed Vali Reza. "International Politics, Domestic Imperatives, and Identity Mobilization: Sectarianism in Pakistan, 1979-1998." Comparative Politics 32 (2000): 171-90.

56. Fair, C. Christine. "Lashkar-e-Tayiba and the Pakistani State." Survival 53 (2011): 29-52.

57. Khan, Ismail. "The Assertion of Barelvi Extremism." Current Trends in Islamist Ideology 12 (2011): 51-72.

58. Jamal, Arif. Shadow War: The Untold Story of Jihad in Kashmir. Brooklyn: Melville House, 2009.

59. Naqvi, Feisal H. “An Unholy Alliance.” Express Tribune, 25 February 2013. Available online: http://tribune.com.pk/story/512400/an-unholy-alliance/ (accessed on 1 September 2015).

60. Staniland, Paul. “Armed Groups and Militarized Elections.” International Security Studies, 15 March 2015. Available online: http://onlinelibrary.wiley.com/doi/10.1111/isqu.12195/abstract (accessed on 1 September 2015).

61. BFRS Dataset. Available online: https://esoc.princeton.edu/files/bfrs-political-violence-pakistandataset (accessed on 1 September 2015).

62. Tessler, Mark, and Michael D. H. Robbins. "What Leads Some Ordinary Arab Men and Women to Approve of Terrorist Acts Against the United States?" Journal of Conflict Resolution 51 (2007): 305-28.

63. Laqueur, Walter. The New Terrorism: Fanaticism and the Arms of Mass Destruction. New York: Oxford University Press, 1999.

64. Calvert, John. "The Islamist syndrome of cultural confrontation.” Orbis 46 (2002): 339-49.

65. Mendelsohn, Barak. "Sovereignty under Attack: The International Society Meets the Al Qaeda Network." Review of International Studies 31 (2005): 45-68.

66. Jackson, Richard. "Constructing Enemies: Islamic Terrorism in Political and Academic Discourse." Government and Opposition 42 (2007): 394-426.

67. Juergensmeyer, Mark. Terror in the Mind of God: The Global Rise of Religious Violence. Berkeley: University of California Press, 2003, vol. 13.

68. Juergensmeyer, Mark. Global Rebellion: Religious Challenges to the Secular State, From Christian Militias to Al Qaeda. Berkeley: University of California Press, 2008, vol. 16.

69. Weinberg, Leonard, Ami Pedahzur, and Daphn Canetti-Nisim. "The Social and Religious Characteristics of Suicide Bombers and Their Victims." Terrorism and Political Violence 15 (2003): 139-53.

70. Hafez, Mohammed M. "Martyrdom Mythology in Iraq: How Jihadists Frame Suicide Terrorism in Videos and Biographies." Terrorism and Political Violence 19 (2007): 95-115.

71. Wiktorowicz, Quintan. Radical Islam Rising: Muslim Extremism in the West. Lanham: Rowman \& Littlefield Publishers, 2005.

72. Tessler, Mark, and Jodi Nachtwey. "Islam and attitudes toward international conflict: Evidence from survey research in the Arab world." Journal of Conflict Resolution 42 (1998): 619-36. 
73. Clingingsmith, David, Asim Ijaz Khwaja, and Michael R. Kremer. "Estimating the impact of the Hajj: Religion and tolerance in Islam's global gathering." Quarterly Journal of Economics 124 (2009): 1133-70.

74. Fair, C. Christine, Rebecca Littman, and Elizabeth Nugent. "Pakistani Conceptualization of Shari's and Support for Militancy and Democratic Values: A New Empirical Approach.” 2014. Available online: http://papers.ssrn.com/sol3/papers.cfm?abstract_id=2482547 (accessed on 1 September 2015).

75. Ginges, Jeremy, Ian Hansen, and Ara Norenzayan. "Religion and support for suicide attacks." Psychological Science 20 (2009): 224-30.

76. Kaltenthaler, Karl, William J. Miller, Stephen Ceccoli, and Ron Gelleny. "The Sources of Pakistani Attitudes toward Religiously Motivated Terrorism.” Studies in Conflict \& Terrorism 33 (2010): 815-35.

77. Furia, Peter A., and Russell E. Lucas. "Arab Muslim Attitudes toward the West: Cultural, Social, and Political Explanations.” International Interactions 34 (2008): 186-207.

78. Fair, C. Christine, Clay Ramsay, and Steve Kull. Pakistani Public Opinion on Democracy, Islamist Militancy, and Relations with the US. Washington: United States Institute of Peace, 2008.

79. Chiozza, Giacomo. "How to Win Hearts and Minds? The Political Sociology of the Support for Suicide Bombing." 2010. Available online: http:/www.elecdem.eu/media/universityofexeter/ elecdem/pdfs/giacomochiozzatraining/How_to_Win_Hearts_and_Minds.pdf (accessed 16 September 2015).

80. Tessler, Mark. "Arab and Muslim Political Attitudes: Stereotypes and Evidence from Survey Research.” International Studies Perspectives 4 (2003): 175-81.

81. Tessler, Mark. "The nature and determinants of Arab attitudes toward Israel." In Contemporary Anti-Semitism: Canada and the World. Edited by Michael Robert Marrus, Derek Jonathan Penslar and Janice Gross Stein. Toronto: University of Toronto Press, 2004, pp. 96-121.

82. Shikaki, Khalil. "Willing to Compromise: Palestinian Public Opinion and the Peace Process." U.S. Institute of Peace, Special Report 158. 2006. Available online: http://www.usip.org/ publications/willing-compromise-palestinian-public-opinion-and-the-peace-process (accessed 16 September 2015).

83. Ali, Saleem H. Islam and Education: Conflict and Conformity in Pakistan's Madrassahs. Karachi: Oxford University Press, 2009.

84. Haqqani, Husain. "The Ideologies of South Asian Jihadi Groups." Current Trends in Islamist Ideology 1 (2005): 12-26.

85. Rana, Muhammad Amir. The A to $Z$ of Jehadi Organizations in Pakistan. Translated by Saba Ansari. Lahore: Mashal, 2004.

86. Fair, C. Christine, Neil Malhotra, and Jacob N. Shapiro. "Islam, Militancy, and Politics in Pakistan: Insights from a National Sample." Terrorism and Political Violence 22 (2010): 495-521.

87. Jahan, Muska. "Stop Calling Each Other Hojabis-Hijabi Problems." 28 March 2015. Available online: http://muskajahan.com/2015/03/stop-calling-each-other-hojabis-hijabi-problems/ (accessed on 1 September 2015).

88. Khan, Zeba. "Red Wine and Hojabis: A Judgment on Being Judgmental.” Muslimmatters.org, 10 February 2014. Available online: http://muslimmatters.org/2014/02/10/red-wine-hojabisjudgment-judgmental/ (accessed on 1 September 2015). 
89. Tanda. "The Myth of the 'Hojabi'; a Ramadan Reminder.” The Alternative Muslim, 3 August 2011. Available online: https://thealternativemuslim.wordpress.com/2011/08/03/the-myth-of-the-hojabia-ramadan-reminder/ (accessed on 1 September 2015).

90. Fair, C. Christine. The Madrassah Challenge: Militancy and Religious Education in Pakistan. Washington: United States Institute of Peace, 2008.

91. Fair, C. Christine, Rebecca Littman, Neil Malhotra, and Jacob N. Shapiro. "Relative Poverty, Perceived Violence, and Support for Militant Politics: Evidence from Pakistan.” 2015. Available online: http://www.princeton.edu/ jns/papers/FLMS_2013_Poverty_Violence_Support_for_ Militancy.pdf (accessed on 16 September 2015).

92. Fair, C. Christine, Neil Malhotra, and Jacob N. Shapiro. "Faith or Doctrine? Religion and Support for Political Violence in Pakistan.” Public Opinion Quarterly 76 (2012): 688-720.

93. Shafiq, M. Najeeb, and Abdulkader H. Sinno. "Education, income and support for suicide bombings: Evidence from six Muslim countries." Journal of Conflict Resolution 54 (2010): 146-78.

94. Asal, Victor C., Christine Fair, and Stephen Shellman. "Consenting to a Child's Decision to Join a Jihad: Insights from a Survey of Militant Families in Pakistan." Studies in Conflict and Terrorism 31 (2008): 973-94.

95. Hussain, Azhar, Ahmad Salim, and Arif Naveed. Connecting the Dots: Education and Religious Discrimination in Pakistan A Study of Public Schools and Madrassas. Washington: United States Commission on International Religious Freedom, 2011. Available online: http:// www.uscirf.gov/sites/default/files/resources/Pakistan-ConnectingTheDots-Email(3).pdf (accessed on 1 September 2015).

96. Qadeer, Mohammad. Pakistan-Social and Cultural Transformations in a Muslim Nation. New York: Routledge, 2006.

97. Shaikh, Farzana. "Islamisation to Shariatisation: Cultural transnationalism in Pakistan." Third World Quarterly 29 (2008): 593-609.

98. Ahmad, Sadaf. Transforming Faith: The Story of Al-Huda and Islamic Revivalism among Urban Pakistani Women. Syracuse: Syracuse University Press, 2009.

99. Khan, Zafarulla. "Cyberia: A New Warzone for Pakistan's Islamists." In Pakistan's Counterterrorism Challenge. Edited by Moeed Yusuf. Washington: Georgetown University Press, 2014, pp. 69-186.

100. Rubin, Barnett. The Fragmentation of Afghanistan: State Formation and Collapse in the International System, 2nd ed. New Haven: Yale University Press, 2002.

101. International Crisis Group. "Reforming Pakistan's Criminal Justice System.” 2010. Available online: www.crisisgroup.org/en/regions/asia/south-asia/pakistan/196-reforming-pakistanscriminaljustice-system.aspx (accessed on 31 August 2015).

102. Abbas, Hassan. Reforming Pakistan's Police and Law Enforcement Infrastructure: Is it Too Flawed to Fix? Washington: US Institute of Peace, 2011.

(C) 2015 by the author; licensee MDPI, Basel, Switzerland. This article is an open access article distributed under the terms and conditions of the Creative Commons Attribution license (http://creativecommons.org/licenses/by/4.0/). 